\title{
The Yarra Bend Asylum, near Melbourne.
}

The lunatic asylum for the great colony of Victoria is at Yarra Bend, Melbourne, and contains upwards of 700 patients. This asylum has been under the superintendence of Dr. Bowie, who, in May last, brought an action for libel against the proprietors of the 'Melbourne Argus,' for various articles in that paper impeaching the excellency of his management. The 'Argus' pleaded justification, and thereupon ensued a nine days' trial, the report of which would, at least, fill two numbers of this Journal. Except on one point, namely, the alleged pregnancy of a patient, who turned out to have been a servant, the plea of justification was maintained. The revelations of the trial form an admirable picture of the old concomitants of restraint; it is like reading from the reports of the Parliamentary Committee in 1815. There is neither novelty nor instruction in it that we should cumber our pages with any lengthened account of the manner in which lunatics are treated in the richest of our colonies. The following extract is from the evideuce of Mr. Whittenbury, a surgeon, who recounts what he saw when he was visiting the asylum to see a friend.

"I will mention one particular circumstance. Having heard that there were patients under restraint at Yarra Bend, and not having seen anything of the kind, I asked Dr. Bowie if he would show me some patients under restraint. He said, ' $\mathrm{Oh}$, yes; I will show you several.' He showed me one case. I believe the patient was a man named McDonald-a tall, powerful man. I believe he had not been attended to for several days. At all events, Dr. Bowie said-calling to some of the keepers - We had better attend to this case now; Dr. Whittenbury wants to see it.' At a given signal, the bolts were shot, and four attendants sprang into the cell. Two of the men seized the patient by the neck and shoulders, and the others seized him by the legs. The four men then threw him upon the ground, and held him there, while a fifth attendant removed some straw and dirty things out of the cell. This occurred about four or five o'clock in the evening. The cell was very dirty. The attendant who took the straw away afterwards returned with some clean sheets and a blanket or rug. The patient was naked, with the exception of having on what is called a lunatic or skeleton jacket, which fastened the upper portion of the arms to the breast. To effect their escape from the cell, the attendants bound the patient's legs and feet together, and then rushed out, and bolted the door after them. The lunatic's strength was so great that he immediately jumped up, and almost instantaneously burst his bonds asunder, and sprang at the grating of the cell. I had never seen such a case 
in my life before, and was quite shocked. The cell was a stone cell. No doubt the circumstance of the four men springing upon the lunatic irritated him. I should think it was altogether unnecessary to use such violence, from what I have read as to the treatment of violent lunatics."

This is just old-fashioned brutality, and the rage and fear which it generates; but Dr. Bowie was an ingenious man, and did not by any means adhere to the old path. As an example of this, take his method of preventing escapes by padlocking patients together. O'Grady, an attendant, said ; "In one case, in which two patients tried to run away, they were put in jackets and padlocked together, side by side. They only remained in that position five or six days. They were connected together in that manner all the day, except at meal hours, but not at night."

Dr. Bowie freely admits the fact, and explains it thus :

"Melbourne and Hughes combined together to effect their escape, and Melbourne got upon the parapet of a wall with that object in view. I therefore considered that I was justified in fastening them together. It was done without any ill-nature, but for the purpose of making them tired of each other's company, and preventing them associating with each other for the future. The restraint did not cause them any pain. I had used it with two patients before, for the same object, and it answered exceedingly well. In that case, the two men had been exceedingly troublesome, and I fastened them together for two or three days. One of them said, 'If I was only quit of this partnership, I would not behave so again.' He behaved very well after they were separated."

This Siamese-twin plan of restraint was certainly ingenious, but Dr. Bowie's highest flight of invention was his discovery of a peculiar method of restraint, of which, pretty well posted up as we are, we have never before heard. This is Dr. Bowie's own description of the invention, and the manner in which it was used.

The Attorney-General.- " With regard to the bags, will you explain to the jury what they are, and where they were borrowed from?"

"The origin of their invention is very simply told. When I was in practice in Scotland $I$ had the charge of an insane woman, upon whom we could get no strait-jacket or anything else to secure her. $I$ then bethought myself of a sack. We got one, made it into a kind of dress, and put her into it, and I had the satisfaction of seeing that woman cured. I saw the advantages of the thing, and I used it afterwards. It was used in the asylum to keep the patients warm, and to prevent them injuring themselves. An insane person will often throw himself out of bed, leaving his bedclothes behind him; and to prevent him taking cold, we roll him in a blanket, and then put him into the bag. It was never used as a punishment. My 
directions to the attendants were, never to use a jacket or bag without consulting me. If an extreme case arose, a man might be put into a jacket, but I must be told immediately. If an attendant had not done this, he would have been discharged. The bags were of different sizes. None of them were tight. A patient in a bag had more freedom for his hands than in a jacket. My positive instructions were, that if a patient relieved himself in his night-dress, another bag should be put on."

The opinion of the patients who had practical experience of the doctor's ingenious method of keeping them warm, was not quite so complimentary to it as the inventor no doubt would have desired.

Here is the description given of it by Dr. Carr, a much enduring patient:

"I remember being visited by Dr. M'Crea in September, 1858. I had been seven or eight days in continual restraint. A straitwaistcoat, padlocked, with the hands behind, was placed on me in the first instance. It was put on in such a way as to create actual physical torture. Over that waistcoat was placed a bag. There were three or four bags used in the asylum, with all of which I have acquaintance. The bag was not removed by an attendant for seven or eight days, and it was not until I was questioned by Dr. M'Crea that it became known that I succeeded in releasing myself from the jacket in the space of fifty-four hours after it was put on. The bag I could remove and put on at pleasure, so that I might appear, when any one entered the cell, in just the same condition as when the bag was first placed upon me. The jacket was put on in the afternoon, and the bag not until the evening. Before the bag was put on $\mathbf{I}$ managed to make a small orifice in the canvas stitching, and acting on that, and breaking a padlock, I was enabled ultimately to free myself.

"I made a complaint to Dr. M'Crea, and also, I think, to Dr. Eades and Mr. Barker, of the treatment which I had received. The result of this complaint was, that I was replaced in the canvas jacket. Dr. Bowie came to the door of the cell, and said he did not care what orders the Board gave, I should be placed under restraint, and should so remain as long as I was in the asylum. My hands were padlocked up against the shoulder-blades, and I suffered in consequence a greater amount of physical pain. I had not committed, by deed or word, any breach of the regulations. The jacket was kept on about half an hour, when Mr. Barker entered the cell, and by his orders the jacket was removed. I will describe the feelings which I experienced the first night on which I was put into the bag. The bag was composed of strong No. 1 canvas, impervious to water, which was passed over the feet, and slipped up the body, fitting closely, the hands having to be placed flat against the sides. The bag came close round my neck-so close, indeed, that even the bugs could not get ingress 
between the bag and the neck. I continually passed urine into the bag, and there it was next morning, accompanied sometimes with fæcal matter. The head was not protected from vermin, though sometimes by day, and occasionally by night, a stiff carivas cap was added, and padlocked under the throat. My own head was bitten all over with bugs and fleas-particularly bugs."

The poor doctor did not succeed in his intention to describe his feelings, but he said enough to enable us to guess what they must have been like; fastened in a water-tight sack, with his arms close by his sides, his head and face bitten all over with fleas and bugs, particularly bugs, but the sack so tight round his throat that the bugs could not get down, and the whole body in a filthy water-tight stew. Faugh !!!

Dr. Carr does not say that the treatment he endured was barbarous; but Dr. M'Crea, the visiting physician to the asylum, does say so, for the following passage from his evidence refers to the particular occurrence described by Dr. Carr :

"The proportion of patients restrained was large-much larger than it ought to have been. The means of restraint used were bags, jackets, and mittens. Dr. Bowie always represented to me that the bags were used at night, especially in winter-time, to prevent patients catching cold. If they were used only for that purpose, I can't imagine there would be any objection to them. There were a number of restless patients, who would not lie at night with the bedclothes over them, and it was necessary to put on them these bags, which were lined with flannel. - But on the 7th of September, 1858, during an official visit, I found a patient in a bag of a very different character. That patient was Dr. Carr. To the best of my recollection, that bag was not lined with flannel, and it was fastened round the patient's neck. I forget the nature of the fastening - whether it was tied or padlocked. This was in the day-time, when a patient had no bedclothes to kick off. Dr. Carr said he had been there seven days. The bag was not very tight; he could move his arms inside; but the bag was to restrain him, not to keep him warm. I conceived the treatment improper and barbarous, and I ordered Dr. Carr to be taken out of the bag immediately. Dr. Carr was perfectly quiet and perfectly rational. His hands and nails were tolerably clean, and I asked him how he could reconcile that fact with the statement that he had been seven days in the bag. I understood him to say that, in forty-eight hours after he was put in the bag, he managed to free himself."

Here is the account of another patient from the evidence of Thomas Hugman, which is not at all more flattering to the system :

"There was a patient named Fitzgerald. He died on the 22nd of March last, near Dr. Callan's residence. He came up from $\mathrm{H}$ ward. He was very sickly and feeble, and seemed terrified. He was very 
destructive with regard to his clothes, and, in consequence, was put into a bag during the night. It was a narrow kind of bag, made of very rough canvas-what sailors would perhaps call No. 3 canvas. It was very dirty - almost black.

"Fitzgerald was confined in that bag all night. He could not move his arms. He was placed on the bed, and lay there like a mummy. The bag was fastened by leather straps and a padlock. In the day-time, he was put into the airing yard. He had on some patent gloves-canvas gloves without fingers, fastened by a leather strap and padlock which screwed up, and if screwed up tight, would give excruciating pain to any man."

It would appear that the sacks were used very freely. Dr. Michael Barry, who visited the asylum officially, as it would seem, in company with the Mayor of Melbourne, says :

"I have seen most of the principal asylums in France, Ireland, and England. I was struck with the appearance of great despondency presented by the patients at Yarra Bend Asylum. Although things appeared clean to the eye, they were unpleasant to the nose. Almost everywhere there was an offensive smell, particularly in the dormitories and airing ground. There was particularly a smell of urine. That struck me to be the case almost everywhere I went. I thought the per-centage of restraint used at the asylum was most unnecessary. There seemed to be various bags and sacks used for restraint. I saw seven or eight people shut up in things of that kind."

There were complaints about the food also, and the poor patients at Yarra Bend might have exclaimed with Prince Hal, "Oh, monstrous; what, only two pennyworth of bread to all that sack !"

Dr. Bowie, indeed, though not a very wise man, might have been called the great Sackem of Melbourne. However, it is said that he is going, or gone, so that we may infer, argol, that he has himself been invested with the collar and badge of the sack.

There is much more instructive matter in the report of the trial than we are able to extract, which we regret, for we trust that it will be long before we again have such an opportunity of enriching the anthology of restraint. It is an old tale, that the habitual use of restraint is accompanied by everything else which is objectionable in the management of an asylum, and especially by a disregard of all proprieties and decencies, and we are therefore not surprised to find proof of all this in this Yarra Bend trial. Let the following little fact show what the cleanliness of the place must have been. Samuel Wainwright, a former attendant, said: "The wards were cleaned with sand and lime. Soap and water were not used. If there was any dirt the sand and lime would be left on. You can hide dirt with sand and lime, but you cannot remove it."

Dr. Bowie did not deny the fact of his mode of cleaning, and gave the credit of it to the Commissioners in Lunacy. "Hot sand 
and lime were used to scrub out the cells. The patients were not in the cells at the time. The sand and lime were scrubbed off in half an hour after they were put on. That process is recommended by the Commissioners of Lunacy. It takes away all the offensive smell." In the same spirit, we suppose, he made use of Dr. Conolly's authority for fastening patients to their bedsteads at night, and asserted that in every English asylum he had visited, mechanical restraint is used. Of a verity, ideas do seem to stand topsy-turvy at the antipodes.

We are happy to say that the Victorians commissioned the member for Pontefract, our old colonist, to send them out a medical superintendent from home, and that Dr. E. Paley, late of Camberwell House, a member of this association, has been selected for the office, and sailed on Christmas Eve.

Dr. Paley carries with him to his distant home the warm wishes of all who know him. No better man could have been found to represent English Psychology in this distant colony. Dr. Paley combines experience, temper, and judgment, and he has invariably gained the respect and esteeem of all with whom he has worked. We found him a formidable as well as courteous opponent at the election to the Sussex Asylum in 1858. We trust to hear from Dr. Paley of his impressions of the colony of Victoria. The salary of the appointment is $£ 900$, with allowances equal to $£ 400$, including a house.

\section{Death of Sir Benjamin Brodie.}

" On the eve of eighty years, a life not more distinguished by its length than by its usefulness and success, professional and social, came to an end at Brome Park, in Surrey, on Tuesday last. Sir Benjamin Brodie, whose death we have now to chronicle, had long been ailing; the great "medicine man" of our time having been racked with pains in the shoulder-joints, and with disease in the eyes, beyond the power of art to reach. Partial blindness had for some years past clouded his studies, as it had interrupted the discharge of his duties as President of the Royal Society. From the latter office he retired in favour of General Sabine. His mind, however, continued active in his study; he read and took part in the controversies of the day, and to the last kept a ready and flowing pen in his hand. Brodie was born on the 9th of June, 1783, at Winterslow, in Wilts, of which place his father was rector; was educated at home; was placed under Mr. Wilson at the Hunterian School in Great Windmill Street, whence he removed, in 1803, to St. George's Hospital, and became a member of the College in 1805. From that date his rise was steady, being helped by the literary power and professional success of his lectures. On the death of 